\title{
Vapauttava kauneus
}

Schiller, Friedrich 2013. Kirjeitä ihmisen esteettisestä kasvatuksesta.

Suomentanut Pirkko Holmberg. Helsinki: Tutkijaliitto. $160 \mathrm{~s}$.

ISBN 978-952-5169-95-9

PIRKKO HOLMBERGIN äskettäin suomeksi kääntämää teosta voi sanoa todelliseksi klassikoksi. Aina uudet sukupolvet ovat ammentaneet siitä innoitusta. Nuori Marx viehättyi sen yhteiskuntakritiikistä. Toisen maailmansodan jälkeen Schillerissä nähtiin varhainen vieraantumisen kuvaaja. Frankfurtin koulukunnan teksteissä Schiller vilahtelee kriittisen perspektiivin rakentajana.

"Kirjeet" ilmestyivät alun perin Schillerin toimittamassa kulttuurilehdessä nimeltä Horen vuonna 1795. Editoituina "kirjeet" ovat sittemmin sisältyneet moniin hänen teoksistaan koostettuihin laitoksiin.

Nyt käsillä olevan suomennoksen pohjana on julkaisu Schillers Werke Nationalausgabe Bde XXXXI vuodelta 1963. Samoja teemoja Schiller kuitenkin käsitteli jo paria vuotta aikaisemmin kirjeissään tanskalaiselle Augustenburgin prinssille.

Mainittu prinssi myönsi Schillerille huomattavan apurahan ja vaikkei hänelle asetettu raportointivelvollisuutta, katsoi hän asianmukaiseksi kertoa mesenaatille tekemisistään. Pahaksi onneksi prinssin linnassa sattui tulipalo ja kirjeet tuhoutuivat. Osa kirjeistä oli kuitenkin ehditty kopioida ja ne säilyivät jälkimaailmalle. Nämä ns. Augustenburgin kirjeet on suunnattu sivistyneelle maallikolle ja sellaisina ne käsittelevät asioita suoremmin ja konkreettisemmin kuin vahvasti tyylitellyt Horenlehden kirjeet. Siksi edellisiä onkin pidetty eräänlaisina selkokielisinä versioina jälkimmäisille.

\section{SELKEÄ SUOMENNOS VAIKEASTA TEKSTISTÄ}

"Kirjeitä" moitittiin vaikeaselkoisiksi jo ilmestymisvuonna. Saksankieliset lukijat toivoivat ilkikurisesti niiden kääntämistä saksaksi. Mutta ehkä se oli vitsailua ystävien kesken.

Schiller kuitenkin otti sen siinä määrin todesta, että puolusti moneen otteeseen tyyliään. Lukijalla on luonnollisesti lukemaan ryhtyessään tiettyjä odotuksia esityksen lajista. Jos ne eivät täyty, hän on ärtynyt tai hämmentynyt. Epäilemättä lukija, joka odottaa tieteellisen esityksen eksaktisuutta, systemaattisuutta ja läpinäkyvyyttä, pettyy. Schiller tarjoaa runollisia kielikuvia ja kreikkalaisesta mytologiasta poimittuja metaforia silloin kun pitäisi argumentoida. Hän vaihtelee pitkin matkaa termejä puhuessaan samoista asioista ja käyttää samaa termiä tarkoittamaan monia eri asioita.

Kommentoidessaan muita ajattelijoita Schiller tuo heidät tekstiin nimiä mainitsematta, jolloin lukijan arvattavaksi jää, kenestä kulloinkin on kysymys. Nykylukijan kaipaamat lähdeviitteet ja lähdeluettelo luonnollisesti puuttuvat. Tiedetään, että Schiller 1790-luvun alussa luki systemaattisesti Kantin teoksia, mutta ilmeisesti myös Fichte ja Reinhold ovat olleet merkittäviä ajatteluainesten antajia. Schillerille on myös ominaista Nietzschen tapaan haluttomuus lokeroida sanottavaansa filosofian eri osa-alueiden mukaisesti.

Niinpä hän sitten käsittelee suppeassa tekstissä toisiinsa kietoutuneina metafysiikkaa, antropologiaa, estetiikkaa, kasvatusta, politiikkaa. Suomennos on alkutekstin vaikeuden huomioon ottaen varsin selkeä. 


\section{UUSI NÄKÖKULMA VASTAKKAISASETTELUUN}

"Kirjeiden" merkityksen arviointi vaatii niiden tarkastelua ainakin kahdessa viitekehyksessä: yhtäältä karteesiolaisen dualismin ja toisaalta yhteiskuntakehityksen yhteydessä. Descartesin maailmanmalli muodostui kahdesta toisilleen olemusvieraasta substanssista: ajattelevasta ei-ulottuvasta ja ulottuvasta ei-ajattelevasta.

Tämä perusvastakkaisuus esiintyi monina variantteina: luonto contra järki, aine contra henki, välttämättömyys contra vapaus. Luontoon sijoitettiin aukoton kausaalinen välttämättömyys, järjen maailmaan moraalinen ja looginen.

Kahden erillisen maailman suhde oli pysyvä ongelma ja siihen esitettiin mitä merkillisimpiä ratkaisuja. Ihminen oli kahden maailman asukki samanaikaisesti: tunteet, aistimukset ja kuvittelukyky olivat ruumista, looginen ja moraalinen päättely, ajattelu ylipäänsä, henkeä.

Valistusajattelulla oli taipumus korostaa järkeä ja väheksyä ihmisen ruumiillista puolta. Se oli ikään kuin epävarsinaista olemista. Se oli luontoa, joka ihmisen tuli tukahduttaa itsessään. Schiller tuo uuden näkökulman vallitsevaan dualismiin. Hän ehdottaa esteettisen aluetta järjen ja luonnon kohtauspaikaksi.

\section{"VINOJA" SPESIALISTEJA}

Vaikka valistuksen vuosisataa ei ole totuttu pitämään historian tutkimuksen kulta-aikana, osoittautuu, että yksi ja toinen aikakauden merkittävistä ajattelijoista rakenteli mielessään ihmiskunnan (tai -suvun) kehityshistoriaa.

Mainittakoon vain nimet Hume, Voltaire, Rousseau, Kant, Herder, Pestalozzi Schillerin lisäksi. Tällaisten pakostakin vielä spekulatiivisten historioiden luonnollinen osa on arvio ihmiskunnan tilasta ja tulevaisuudesta. Optimistit uskoivat, että lähitulevaisuudessa siirrytään luonnonpakon sanelemasta järjestyksestä järjen kantamaan poliittiseen vapauteen. Silmissä siintelivät demokratia ja laajat kansalaisoikeudet. Rousseau ja Schiller kuitenkin suhtautuivat tällaiseen edistysuskoon varsin varauksellisesti.

Schiller kuvaa kuudennessa kirjeessä synkin värein aikansa yhteiskuntaa. Se on kuin kellokoneisto, jonka rattaita ihmiset ovat. Työstä on hävinnyt nautinto. Keinot ovat kadottaneet yhteyden päämääriin. Ihmiset ovat niin läpikotaisin toimensa leimaamia, ettei ihmisyydelle ole tilaa. Valtio on vain voima muiden voimien joukossa.

Toisin sanoen elämän mieli on kadoksissa. Pitkälle viety työnjako sekä säätyjärjestelmä eriyttävät ja erilaistavat ihmiset. Kyvyiltään tasapainoisen ehyen ihmisen sijaan on vain "vinoja" spesialisteja.
Yksilön kohdalla ihmisyys toteutuu varsin yksipuolisesti. Schiller myöntää, että ihmiskunnan kehitys vaatii erikoistumista. Mutta onko edistyksen hyväksi uhrattava yksilö?

\section{KAKSI PERUSVIETTIÄ: AISTIVIETTI JA MUOTOVIETTI}

Schiller pettyi perusteellisesti Ranskan vallankumoukseen. Hänestä kaivattu ihmiskunnan uusi alku kääntyi mielivallaksi, murhaamiseksi ja ryöstelyksi. Onnekas sattuma soi Ranskan kansalle tilaisuuden, mutta se ei ollut kypsä ottamaan vastaan järjen valtaa. Pelkkä ulkoisen pakon höltyminen ei tee ihmisistä vapaita. Eivät irti päästetyt ole vapaita: he ovat viettiensä ja intohimojensa vankeja. (5. kirje)

Schillerin arvion mukaan ihmiskunta tarvitsi ainakin sadan vuoden valmennuksen ennen kuin se oli valmis astumaan yhteiskuntaan, jossa kansalaiset ovat lähtökohtaisesti vapaita (7. kirje). Marx tunnetusti oli tässä eri mieltä. Hän uskoi, että ihminen muuttaessaan olosuhteitaan muuttuu itsekin. Vallankumouksellinen prosessi itsessään kasvatti.

Kirjansa ydinsanoman Schiller tuo esiin jo toisessa kirjeessä: estetiikka ja poliittinen vapaus kytkeytyvät toisiinsa. Tie vapauteen kulkee ainoastaan kauneuden kautta, Schiller vakuuttaa.

Väitteen perustelu vaatii ekskursion antropologiaan. Schillerin 
mukaan ihmistä määrittää kaksi perusviettiä: aistivietti ja muotovietti. Edellinen sitoo ihmisen ajallis-aineelliseen maailmaan. Se on vastaanottava kyky, jonka toiminta ilmenee aistimuksina ja tunteina. Jälkimmäinen ankkuroituu järkeen. Se antaa koetulle muodon. Siitä ovat peräisin sekä moraaliperiaatteet että asioiden looginen jäsennys. Kun ihminen ajattelee, hän on muotovietin alainen. Vietit rajaavat vastavuoroisesti toisensa. Voimina ne kumoavat toisensa silloin kun ne ovat saman suuruiset. Syntyy vapauden tila, joka ihmiselle ilmenee kauneuden kokemuksena. Tässä vapauden tilassa operoi leikkivietti.

\section{KEHITYSKULKU FYYSISESTÄ MORAALISEEN}

Riippuen siitä, mikä vietti on hallitseva, Schiller puhuu fyysisestä, esteettisestä ja moraalisesta tilasta (24. kirje). Tilat ovat samalla sekä ihmisyksilön että ihmiskunnan välttämättömät kehitysvaiheet.

Aluksi ihminen lajina on välitön osa luontoa. Askel seuraavaan vaiheeseen on pitkä. Voi ihmetellä, miksi se ylipäänsä tapahtuu. Schiller sanoo, että suosiollinen sattuma irrottaa fyysisen tilan kahleet ja johdattaa villin kohti kauneutta. (26. kirje) Kauneuden kautta ihminen pääsee moraaliseen tilaan, jossa hän voi antaa luonnolle lait. Poliittisen vapauden ehto on siis onnistunut esteettinen kasvatus.
Kehityskulku fyysisestä moraaliseen tilaan ei ole suoraviivainen ja itsestään selvä. Schiller tuo esiin erään mahdollisen vääristymän. Kun aistimellinen ihminen herää kaipaamaan jotakin ehdotonta ja välttämätöntä, hän ei ilman muuta nouse yleiseen ja ideoihin, vaan ahtaan egoisminsa rajoissa asettaa oman yksilöllisen olemassaolonsa ja hyvinvointinsa korkeimmalle. Äärimmillään oma olemassaolo pyritään turvaamaan rajattomaksi ajaksi. (24. kirje)

Kuulostaa tutulta. Oman aikamme epävarmuuden ja rajattoman kilpailun oloissa yksilön koko elämän täyttää pyrkimys toimeentulon varmistamiseen. Oppilaitoksissa työelämä on yhä vahvemmin läsnä. Työelämä asettaa rajat myös tieteelliselle mielikuvitukselle.

\section{KRIITTINEN NÄKÖKULMA}

\section{PARASTA ANTIA}

Mitä nykylukija saa Schillerin "kirjeistä"? Ainakin Schiller muistuttaa taideaineiden merkityksestä ihmisen kehitykselle ja hyvinvoinnille. Niitä on opetussuunnitelmassa varjeltava tietoaineiden paisumistaipumukselta.

Vallankumouksen opas teos ei ole, vaikka Schiller puhuukin paljon vapautumisesta poliittisessa mielessä. Kasvatuksen käsittely jää yleisluonteiseksi. Toki teos muistuttaa, että tunteet ansaitsevat kasvattajan täyden huomion.
Tärkeintä "kirjeissä" on kriittinen perspektiivi, jossa on antoisaa tarkastella kulloinkin ajankohtaisia ilmiöitä.

Teos sopii mainiosti sellaisiin yliopiston seminaareihin, joissa tutkitaan kasvatuksen kannalta tärkeitä klassikkoja. Kai sellaisiakin seminaareja vielä on, vaikkei klassikkojen tuntemus takaa menestystä työelämässä.

Jyrki Hilpelä eläkeläinen, Joensuu 